\title{
The NPM: The Trojan Horse in Accountability
}

\author{
Ron Kluvers \\ Faculty of Business and Enterprise, Swinburne University \\ Hawthorn, Melbourne 3122, Australia \\ Tel: 61-3-9214-8435Ｅ-mail: rkluvers@swinburne.edu.au \\ John Tippett (Corresponding author) \\ Centre for International Corporate Governance Research \\ Victoria University \\ PO Box 14428 MC, Melbourne 8001, Australia \\ Tel: 61-3-9919-1058Ｅ-mail: john.tippett@vu.edu.au
}

Received: October 4, 2011

Accepted: October 14, $2011 \quad$ Published: February 1, 2012

doi:10.5539/ijbm.v7n3p3

URL: http://dx.doi.org/10.5539/ijbm.v7n3p3

\begin{abstract}
This empirical study is an attempt to understand the impact of the New Public Management (NPM) on accountability within Victorian local government. The NPM has changed the parameters of public decision-making. It is appropriate therefore to consider the effect of the NPM on the concept of accountability held by staff and councillors of Victorian municipalities.

Data were collected from 79 Victorian municipalities. A survey instrument was distributed to councillors and managers, with survey statements eliciting participants' understanding of the operation of accountability. The responses of a number of statements were cross-tabulated revealing some statistically significant associations that revealed the effect of the NPM on the understanding of accountability. Respondents' views revealed an understanding of accountability in which stewardship was considered to be important but strongly influenced by the NPM.
\end{abstract}

Keywords: Accountability, Local government, New Public Management, Performance

\section{Introduction}

The New Public Management (NPM) has had a significant impact on the public sector in many western countries. In particular, we are interested in investigating the consequences for accountability of the introduction of the NPM into local government. While accountability may be difficult to define (Ebrahim, 2003; Goddard, 2005) there is a consensus that it involves a rendering of an account and therefore the provision of information. Accountability is established when an agent accepts resources and responsibilities entrusted by the principal.

With the adoption of the NPM (Hood, 1995) a private-sector version of management has been imported into the public sector, resulting in a more "business-like" management style that emphasises efficiency, performance measurement and contracting out, and has thereby changed accountability. The "new" accountability has also been cast in terms of the principal/agent relationship, but in which the agent is accountable exclusively to the principal in terms of meeting the information demands of that party (Parker and Gould 1999). Historically, accountability has emphasised stewardship and considered the interests of all relevant parties, not just those of the principal. Funnell $(2001,2003)$ argues that this has changed - that the focus of the "new" accountability is managerial, with a strong emphasis on compliance. Managerial accountability has replaced stewardship as the core of accountability.

Horton (2006) suggests that the changes associated with new public management (NPM) have had an impact on systems of public administration and public officials. These changes affect both the understanding of accountability and the processes supporting it. 
To gain a better understanding of the impact of the NPM on accountability in the modern context, we intend to explore the understanding of local government managers and councillors of accountability, consequent upon their having been exposed to the NPM for a substantial period of time - in the order of two decades. Using survey data, this paper shows that there are discreet aspects of the NPM with respect to accountability.

In the next section is the literature dealing with the nature of accountability, with specific reference to an NPM focus. This will be followed by the research question and an explanation of the research method, and then the reporting of results. Finally, the implications of the research results will be discussed and the conclusions that can be drawn from this empirical study.

\section{Accountability and the NPM}

In the public sector there is now an increasing emphasis on planning, budgeting and service delivery (Goddard, 2005); and hence a lessening of the differences between the public and private sectors (Hood, 1995). This has, according to Broadbent and Laughlin (2003), meant a redefining of accountability from political accountability to managerial accountability, underscored by the principles of the NPM (Funnell, 2001). Further, Funnell (2003) argues that accountability is being weakened because of the NPM emphasis on accomplishments, progress and performance. Service delivery, according to Funnell, has been changed from a political activity to a technical issue, therefore placing greater emphasis on technical information such as accounting, budgeting, and performance measurement. Further, these predominantly quantitative measures provide information about efficient performance, which is related to the managerial aspect of accountability, rather than effective service delivery, which is related to the public/political aspect of accountability. The emphasis on efficient service delivery and quantitative information changes the nature of accountability, leading to greater control by the executive rather than increased scrutiny of it (Broadbent and Laughlin 2003).

Broadbent and Laughlin (2003) argue that there are, broadly-speaking, two aspects of accountability: public/political accountability that involves the public as principals and is concerned with issues of democracy and trust; and managerial accountability that is concerned with day-to-day operations of the organisation and can be equated with Stewart's (1984) concepts of process, performance and program accountabilities. The production of annual accounting and performance reports exemplifies a concern with the managerial aspect of accountability rather than public or political accountability. Broadbent and Laughlin (2003) argue that, under managerial accountability, the provision of detailed information is not directed to being more accountable to the public but rather it is an attempt by the principals (elected representatives) to control the agents (managers), and to legitimise past decisions and justify future ones. The provision of annual financial statements is an example of legitimising past decisions. Over recent decades the NPM has driven reform in the public sector (Irvine, Lazarevski and Dolnicar, 2009), and so the NPM has had time to influence public sector culture and hence accountability.

One view of accountability is to reduce all accountability relationships to ones of obligation (Foster, 2000). So long as the contract is clear then the obligations within the relationship are clear as are the information needs to monitor the performance of the contract. However, some relationships cannot be accurately defined by a contract (Broadbent and Guthrie, 1992) and therefore, to define accountability in contractual terms limits our understanding of the concept. Kloot and Martin (2001) suggest that there are also social contracts that are important for accountability and which go beyond the legalistic approach suggested by Foster (2000).

In the public sector, accountability relationships are hierarchical involving principal and agent relationships. For example, elected councillors are agents for the citizens that elected them and local government managers are agents for the councillors. Rendering of account requires the agent to provide information about decisions and activities to the principal.

The principal/agent or accountor/accountee relationship is arguably easier to define in a commercial context where contractual relationships are common and understood. In the public sector, accountability relationships appear to have become more contractual in nature (Funnell, 2001), thus shifting accountability within the public sector toward its private sector counterpart. However, accountability in the public sector is complicated by the greater number of accountability relationships such as those between elected officials and managers, between elected officials and citizens and between citizens and managers. Patton (1992) states public sector organisations are not judged by the profits they make or the dividends they declare but rather on the policies that are developed and the extent to which stated objectives have been achieved, hence further differentiating accountability in the two sectors. The argument outlined by Patton equates with public/political accountability, discussed by Broadbent and Laughlin (2003).

The changing nature of accountability is also discussed by Taylor and Rosair (2000), who note that it has 
broadened from stewardship to managerial accountability. They conclude that the predominance of one aspect of accountability depends upon the intended accountees; that is, the participating parties within the structure of government and the public. Taylor and Rosair indicate that the main purpose of external reporting is linked to meeting accountability demands of the participating parties and has little to do with providing accountability to those stakeholders who are not local government employees or councillors. To the extent that this is happeningthat the public is not the focus of accountability - it has important implications for local, indeed all levels of government. Public accountability is a vital component of the Australian system of public life.

Parker and Gould (1999) argue that the move toward a commercial orientation has changed the understanding of accountability in the public sector, indeed Leonard and Onyx (2003) argue that NPM practices involving competition and efficiency have become institutionalised across the public sector. On the one hand private sector ideology, with its production values, is a threat to traditional accountability; but on the other hand, it has broadened the concept of accountability to include performance. Cameron (2004) argues that the reporting of well-documented performance information is now fundamental to public sector accountability. This reinforces the perception that there has been a shift from public/political accountability toward managerial accountability. A significant example of this shift is Victorian local government, which has undergone numerous changes in recent years (Kloot and Martin, 2001). The previous Victorian state government, the Kennett Liberal National Coalition government of 1992 - 1999, introduced compulsory competitive tendering (CCT), with a strong emphasis on performance measurement and efficiency, all hallmarks of the NPM. Accrual accounting, which is consistent with the NPM, was formalised within Victorian local government with the introduction of the Australian Accounting Standard 27 (AAS 27) in June 1996, and from that time on local government accounting was on a business footing.

According to Kloot and Martin local government managers need to balance the requirements of accountability to the community and their accountability for financial outcomes. This is consistent with the findings of Taylor and Rosair (2000). However, Kloot and Martin conclude that local governments in Australia have emphasised accountability to ratepayers and the wider public, but it must be noted that the information being provided is predominantly of a managerial nature rather than that required for public accountability. That is, the NPM appears to be dominating.

Cameron (2004) points out that Key Performance Indicators (KPIs) are largely driven by the budgetary process and are linked to the allocation of resources rather than the attainment of objectives, therefore emphasising managerial rather than political accountability. In addition he suggests that the link to the budget explains the emphasis on efficiency rather than effectiveness, again a characteristic of the NPM.

Patton (1992) contends that it is important for stakeholders to be able to make informed judgements about the performance of public sector entities against stated objectives and the stewardship of public monies. However, the very nature of NPM reporting limits this possibility. That is to say, the NPM emphasis appears to have impacted on the relevance of the reports that are its product - namely, reports to other public sector managers. It therefore excludes the broader community.

\section{Research Issue}

Kloot and Martin (2001) note that much of the accountability literature is normative and little empirical research has been undertaken that examines the impact of the NPM on the perception of accountability held by managers and councillors. Hence, the research question of our paper is:

Has the NPM had an impact on the perception of accountability held by managers and councillors in Victorian local government?

\section{Research Method}

The aim of the research was to determine the extent of influence of the NPM on local government managers' and councillors' perceptions of accountability. The survey instrument was sent to managers and councillors as they are the decision-makers.

The survey instrument was developed on the basis of the issues raised in the literature. The questionnaire was submitted to a number of academics, the Victorian Local Government Association (VLGA) and the Municipal Association of Victoria (MAV) for comments on the appropriateness of the statements and the format of the instrument. Minor adjustments were made as a result of this consultation.

Victorian local government was selected as the environment in which to conduct the research as it is characterised by diversity: in geographic size and location, in population size, in its ability to raise revenue, and in the size and composition of its expenditure. Also, there have been significant developments in Victorian local 
government, such as emphasis on efficiency, contractual relationships, and performance measurement.

Each of Victoria's 79 municipalities was sent two envelopes containing 10 survey instruments and 10 pre-paid return envelopes - one set was for councillors, the other for managers. Most municipalities have fewer than 10 councillors and also fewer than 10 managers - the number in each category varied across municipalities. A covering letter accompanied each set, one addressed to the mayor, the other to the chief executive officer.

The following seven statements from our survey instrument that directly concern the NPM and accountability were selected. We applied a $t$-test to these seven statements and all were significant ( $p=.000$ in all seven cases). Responses were indicated on a seven-point likert scale (and so the $t$-test was against a value of 3.5).

1) Accountability is a very easy concept to define

2) At the centre of the accountability relationship is stewardship

3) Accountability can only be guaranteed by a contractual relationship

4) Compulsory reporting to stakeholders will enhance accountability

5) My council is using a very good set of performance indicators that clearly show whether objectives are being achieved

6) Over the last decade accountability for performance has become increasingly important

7) If a council operates efficiently then it has met all its accountability obligations

These statements were subjected to Cross tabulation analysis, to determine respondents' understanding of the nature of accountability in the light of the NPM.

\section{Discussion of Results}

Table 1 shows that a significant number of respondents agreed that accountability is a very easy concept to define and also agreed with the statement that at the centre of the accountability relationship is stewardship. The stronger support was for the latter statement, indicating that stewardship is still considered to be a key element of accountability. Also, the results show that the majority of respondents believed that accountability as a concept was easy to define. The significant $p$-value indicates that respondents linked accountability with stewardship.

The response reported in Table 2 is equally emphatic with the majority of respondents supporting the statement that at the centre of the accountability relationship is stewardship. A greater number were in agreement with the statement that over the last decade accountability for performance has become increasingly important. The association between the two statements was statistically significant. The greater number of respondents agreeing with the statement that over the last decade accountability for performance has become increasingly important points to the growing role of performance measurement in accountability. Accountability for performance is an element of the NPM, and these results show that respondents associated stewardship with accountability for performance, thus indicating an infiltration of the NPM into the concept of accountability.

The results reported in Table 3 indicate that there is an association between the statements that accountability can only be guaranteed by a contractual relationship and that if a council operates efficiently then it has met all its accountability obligations. Both statements reflect the NPM, and respondents disagreed with both. They do not believe that accountability is merely a contractual matter, nor is it only about efficiency. We believe that this reflects respondents' reluctance with the notions that accountability can only be guaranteed by a contractual relationship, and if a council operates efficiently then it has met all its accountability obligations. This may reflect the results reported in Table 1, where stewardship is still considered to be an important component of accountability.

The majority of respondents agreed with both statements. Both statements are linked to aspects of the NPM: reporting and performance measurement. The $p$-value $(p=.011)$ indicates that there is an association between the two statements, thus indicating an influence of the NPM on councillors' and managers' perceptions of accountability.

The influence of the NPM on perceptions of accountability is further reinforced by the results of Table 5 , where there is a significant association between compulsory reporting and accountability for performance. The majority of respondents agreed with both. Both compulsory reporting and accountability for performance are aspects of the NPM, and the two statements of Table 5 link these two aspects to accountability.

\section{Discussion}

Historically, accountability has emphasised stewardship. The results in Table 1 show that the respondents still 
agree that stewardship is at the centre of accountability. However, Funnell $(2001,2003)$ argues that this has changed - that the focus of the "new" accountability is managerial, with a strong emphasis on performance. Table 2 reveals that stewardship is linked to the growing importance of performance and supports Funnell's argument that managerial accountability has replaced stewardship as the core of accountability.

However, respondents rejected Foster's (2000) notion that accountability could only be guaranteed by contract and that efficiency is the predominant element of accountability. Respondents seem to have had a broader view of accountability. The results of Tables 1 and 3 reveal a continuing perception that stewardship is an important element of accountability. Results reported in Tables 2, 4 and 5 point to an understanding of accountability involving compulsory reporting and performance. The results of Tables 4 and 5 are consistent with the arguments of Taylor \& Rosair (2000), Broadbent \& Laughlin (2003) Cameron (2004); and those of Tables 2 and 5 - the importance of performance - support Stewart (1984), Funnell (2001, 2003) and Cameron (2004).

Central to our findings are respondents' perceptions of the importance of performance and reporting to accountability in local government. This is a direct result of the introduction of the NPM. The NPM is concerned with efficiency, performance, and financial reporting, and is changing the understanding of accountability.

\section{Conclusions}

The answer to the research question is that as a consequence of the introduction of the NPM into Victorian local government, the perception of accountability held by managers and councillors emphasises many of the elements of the NPM, such as performance and reporting. Whilst managers and councillors still regard stewardship as important to accountability, issues of reporting, efficiency and performance appear to be gaining in importance. Thus, in keeping with Horton (2006) we argue that the NPM has changed the nature of accountability.

This paper is an empirical response to comments made by Kloot and Martin (2001) that papers dealing with accountability have been predominantly normative. The perceptions of accountability reported here are those held by managers and councillors in Victorian local government. It is possible that the perceptions of those in other levels of the public sector may be different. We are aware of the limitations of the survey approach we have adopted, and note that in keeping with the suggestion of Horton, further research of a qualitative nature would enrich the understanding of the perception of accountability.

\section{References}

Broadbent, J., \& Guthrie, J. (1992). Changes in the Public Sector: a review of Recent 'Alternative' Accounting Research. Accounting, Auditing and Accountability Journal, 5 (2), 3-31.

Broadbent, J., \& Laughlin, R. (2003). Control and Legitimation in Government Accountability Processes: The Private Finance Initiative in the UK. Critical Perspectives on Accounting, 14, 3-48. http://dx.doi.org/10.1006/cpac.2001.0525

Cameron, W. (2004). Public Accountability: Effectiveness, Equity, Ethics. Australian Journal of Public Administration, 63 (4), 59-67. http://dx.doi.org/10.1111/j.1467-8500.2004.00402.x

Ebrahim, A. (2003). Making Sense of Accountability: Conceptual Perspectives for Northern and Southern Nonprofits. Nonprofit Management \& Leadership, 14 (2), 191 - 212. http://dx.doi.org/10.1002/nml.29

Foster, C. (2000). Two Concepts of Accountability: Is a Bridge Possible Between Them? London: Price Waterhouse Coopers.

Funnell, W. (2001). Government by Fiat: the Retreat from Responsibility. Sydney: University of New South Wales Press.

Funnell, W. (2003). Enduring Fundamentals: Constitutional Accountability and Auditors-General in the Reluctant State. Critical Perspectives on Accounting, 14, 107-132. http://dx.doi.org/10.1006/cpac.2002.0519

Goddard, A. (2005). Accounting and NPM in UK Local Government - Contributions toward Governance and Accountability. Financial Accountability and Management, 21 (2), 191-214. http://dx.doi.org/10.1111/j.1468-0408.2005.00215.x

Hood, C. (1995). The 'New Public Management' in the 1980s: Variations on a Theme. Accounting, Organizations and Society, 20 (2/3), 93-109. http://dx.doi.org/10.1016/0361-3682(93)E0001-W

Horton, S. (2006). New Public Management: Its impact on public servants' identity. International Journal of Public Sector Management, 19 (6), 533-542. http://dx.doi.org/10.1108/09513550610685970

Irvine, H., Lazarevski, K., \& Dolnicar, S. (2009). Strings attached: New Public Management, Competitive Grant Funding and Social Capital. Financial Accountability and Management, 25 (2), 225 - 252. 
http://dx.doi.org/10.1111/j.1468-0408.2009.00475.x

Kloot, L., \& Martin, J. (2001). Local Government Accountability: Explaining Differences. Accounting, Accountability \& Performance, 7 (1), 51-71.

Leonard, R., \& Onyx, J. (2003). Networking through loose and strong ties: an Australian Qualitative study. Voluntas, 14 (2), 189 - 203. http://dx.doi.org/10.1023/A:1023900111271

Parker, L., \& Gould, G. (1999). Changing Public Sector Accountability: Critiquing New Directions. Accounting Forum, 23 (2), 109-135. http://dx.doi.org/10.1111/1467-6303.00007

Patton, J. M. (1992). Accountability and Governmental Financial Reporting. Financial Accountability and Management, 8 (3), 165-180. http://dx.doi.org/10.1111/j.1468-0408.1992.tb00211.x

Stewart, J. (1984). The Role of Information in Public Accountability. In A. Hopwood and C. Tomkins. Issues in Public Sector Accountability. Oxford: Phillip Allan.

Taylor, D., \& Rosair, M. (2000). The Effects of Participating Parties, the Public and Size on Government Departments' Accountability Disclosure in Annual Reports. Accounting, Accountability \& Performance, 6 (1), 77-98.

Table 1. Stewardship and Accountability

At the centre of the accountability relationship is stewardship

\begin{tabular}{|l|l|l|l|l|}
\hline Accountability is a very easy concept to define & Agree & No Opinion & Disagree & Total \\
\hline Agree & 150 & 27 & 25 & 202 \\
\hline No Opinion & 12 & 11 & 7 & 30 \\
\hline Disagree & 57 & 19 & 9 & 85 \\
\hline Total & 219 & 57 & 41 & 317 \\
\hline
\end{tabular}

$p=.002$

Table 2. Stewardship and the Increasing Importance of Performance

\begin{tabular}{|l|l|l|l|l|}
\hline \multicolumn{5}{|c|}{ At the centre of the accountability relationship is stewardship } \\
\hline $\begin{array}{l}\text { Over the last decade accountability for performance } \\
\text { has become increasingly important }\end{array}$ & Agree & No Opinion & Disagree & Total \\
\hline Agree & 204 & 45 & 35 & 284 \\
\hline No Opinion & 3 & 6 & 1 & 10 \\
\hline Disagree & 10 & 6 & 5 & 21 \\
\hline Total & 217 & 57 & 41 & 315 \\
\hline
\end{tabular}

$p=.001$

Table 3. Accountability, Contracts and Efficiency

Accountability can only be guaranteed by a contractual relationship

\begin{tabular}{|l|l|l|l|l|}
\hline $\begin{array}{l}\text { If a council operates efficiently then it has met } \\
\text { all its accountability obligations }\end{array}$ & Agree & No Opinion & Disagree & Total \\
\hline Agree & 10 & 11 & 46 & 67 \\
\hline No Opinion & 1 & 4 & 15 & 20 \\
\hline Disagree & 27 & 10 & 198 & 235 \\
\hline Total & 38 & 25 & 259 & 322 \\
\hline
\end{tabular}

$p=.002$ 
Table 4. Compulsory Reporting and Performance Indicators

\begin{tabular}{|l|l|l|l|l|}
\hline \multicolumn{5}{|c|}{ Compulsory reporting to stakeholders will enhance accountability } \\
\hline $\begin{array}{l}\text { My council is using a very good set of performance } \\
\text { indicators that clearly show whether } \\
\text { objectives are being achieved }\end{array}$ & Agree & No Opinion & Disagree & Total \\
\hline Agree & 149 & 12 & 30 & 191 \\
\hline No Opinion & 21 & 6 & 5 & 32 \\
\hline Disagree & 62 & 5 & 26 & 93 \\
\hline Total & 232 & 23 & 61 & 316 \\
\hline
\end{tabular}

$p=.011$

Table 5. Compulsory Reporting and Increasing Importance of Performance

\begin{tabular}{|l|l|l|l|l|}
\hline \multicolumn{5}{|c|}{ Compulsory reporting to stakeholders will enhance accountability } \\
\hline $\begin{array}{l}\text { Over the last decade accountability for performance } \\
\text { has become increasingly important }\end{array}$ & Agree & No Opinion & Disagree & Total \\
\hline Agree & 219 & 19 & 50 & 288 \\
\hline No Opinion & 6 & 0 & 4 & 10 \\
\hline Disagree & 8 & 4 & 9 & 21 \\
\hline Total & 233 & 23 & 63 & 319 \\
\hline
\end{tabular}

$p=.001$ 